\title{
Enhancing soil drought induced by climate change and agricultural practices: Observational and experimental evidence from the semiarid area of northern China
}

\author{
Jingting Zhang ${ }^{\mathrm{a}, \mathrm{b}, \mathrm{c}}$, Jia Yang ${ }^{\mathrm{c}}$, Pingli An ${ }^{\mathrm{a}, \mathrm{b}, *}$, Wei Ren ${ }^{\mathrm{d}}$, Zhihua Pan ${ }^{\mathrm{a}, \mathrm{b}}$, Zhiqiang Dong ${ }^{\mathrm{a}, \mathrm{b}}$, \\ Guolin Han ${ }^{\mathrm{a}, \mathrm{b}}$, Yuying Pan ${ }^{\mathrm{a}, \mathrm{b}}$, Shufen Pan ${ }^{\mathrm{c}}$, Hanqin Tian ${ }^{\mathrm{c}, \mathrm{e}}$ \\ a College of Resources and Environmental Science, China Agricultural University, Beijing 100193, China \\ b Key Ecology and Environment Experimental Station of the Ministry of Agriculture for Field Scientific Observation in Hohhot, Wuchuan, Hohhot 011705, China \\ c International Center for Climate and Global Change Research, Auburn University, Auburn, AL 36849, USA \\ d Department of Plant \& Soil Sciences, College of Agriculture Center, Food and Environment, University of Kentucky, Lexington, KY 40506, USA \\ e State Key Laboratory of Urban and Regional Ecology, Research Center for Eco-Environmental Sciences, Chinese Academy of Sciences, Beijing 100085, China
}

\section{A R T I C L E I N F O}

\section{Keywords:}

Soil drought

Climate change

Agricultural practice

Water consumption

Semiarid area in northern China

\begin{abstract}
A B S T R A C T
Increased water scarcity has led to a decade-long soil drought in the semiarid area of northern China, which caused food insecurity in this region. However, there is a lack of sufficient observational evidence about how climate change and agricultural practices have interactively affected this soil drought. Long-term in situ soil moisture measurements collected in agricultural experimental plots indicate that the mean temperature and precipitation during the growing season have reduced soil moisture by $11.2 \%$, and agricultural practices have aggravated the soil drying trend in the $0-100 \mathrm{~mm}$ soil layer over the past three decades. Our results also show that planting water-expensive crops (e.g., potato and maize) may aggravate soil drought. Crop rotation increases soil water consumption by $8.9-12.6 \%$ over continuous cropping. Excessive fertilizer use increases water consumption by $25.4-46.9 \%$ and decreases the water use efficiency (WUE) by $14.6-35.3 \%$, while tillage accounts for the consumption of $10.3 \%$ more soil moisture than no-tillage. Our results indicate that agricultural practices, including crop rotation, a high fertilizer input, and tillage, may increase water consumption and aggravate soil drying. Our findings call for effective strategies for mitigating soil drought in semiarid regions, such as an adjustment of the cropping system, reduced fertilizer use, and improved conservation tillage.
\end{abstract}

\section{Introduction}

Droughts have become more intense and frequent since the 1980s in the context of climate change (Trenberth et al., 2014), especially in the semi-arid regions of the Northern Hemisphere (Wetherald and Manabe, 2002). Previous studies have suggested that the intensification of agricultural activities can change the dynamics of soil moisture due to its impact on infiltration, permeability, the water holding capacity and the moisture loss rate of the soil (Shaxson and Barber, 2003). Climate change and agricultural intensification may cause soil drought when available water in soil layers is lower than crop water demand (Leng et al., 2015; Sheffield and Wood, 2008). Soil drought may further deteriorate to agricultural drought, during which water shortages under a threshold last for an extensive period (Wang et al., 2011a). Agricultural drought is usually associated with crop reduction or failure, leading to a more direct and immediate impact on crop production than climatic stresses (Wang et al., 2011b; Ren et al., 2012; Leng et al., 2015).

China has frequently been affected by droughts due to substantial interannual and decadal variations in precipitation and temperature (Ma and Fu, 2003; Dai et al., 2004; Tian et al., 2016). The average grain loss associated with agricultural drought is approximately 39.2 billion $\mathrm{kg}$ /year, and since 1978, the average economic loss has accounted for $1.47 \%$ of the country's gross domestic product (Leng et al., 2015; MWRC, 2011). Northern China is home to $40 \%$ of the Chinese people, and it contains as much as 65\% of China's arable land (PCOC, 2011; Liu et al., 2015), but only has $18 \%$ of China's water resources (Wang et al., 2011a; Ma and Fu, 2006). This water scarcity is even more severe in the semi-arid region of northern China (SANC) due to its ecological vulnerability and sensitivity to climate change (Deng et al., 2006; Seneviratne et al., 2010; Tian et al., 2016). People tend to use large amounts of water for enhancing food production. However, it has

\footnotetext{
* Corresponding author at: College of Resources and Environment Sciences, China Agricultural University, No. 2, Yuan Ming Yuan West Road, Haidian, Beijing 100193, China.

E-mail address: anpl@cau.edu.cn (P. An).
} 
induced severe environmental problems such as water and soil loss, desertification, grassland degradation, soil salinity, and land subsidence (Li et al., 2015; Liu et al., 2015). From both food and ecological security perspectives, therefore, it is critical to investigate the effect of climate change and agricultural practices on soil drought for mitigating agricultural drought and associated ecological problems.

Previous studies investigated the impact of climate change on soil moisture via either model simulations or satellite-retrieved soil moisture data (e.g., Holsten et al., 2009; Piao et al., 2010; Dorigo et al., 2012). Indications are that the warming and drying trends may lead to changes in evapotranspiration (Thomas et al., 2000; Pan et al., 2015) and crop water demand (Tao et al., 2003), thereby reducing soil moisture and aggravating soil drought. For example, Holsten et al. (2009) found that warming decreased soil moisture by $4-15 \%$ in nature conservation areas in Brandenburg, Germany during 1951-2003 and that future climate change is expected to lead to a further decrease in soil moisture. Wang et al. (2011a) found that soil moisture droughts have become more severe, prolonged, and frequent during the past 57 years in the context of global warming, especially in northeastern and central China, which shows increased susceptibility to soil drought. Some studies have suggested that agricultural practices (e.g., crop type selection, farming measures, fertilizer application, and irrigation management) may affect water use efficiency and soil moisture dynamics by changing the physical and biogeochemical processes of ecosystems (Alley et al., 2003; Rosenzweig et al., 2008; Tian et al., 2011). For example, the vegetation type has a strong effect on soil moisture dynamics (Holsten et al., 2009). Fertilizer use can increase transpiration, deplete soil moisture, and lead to soil drought in rain-fed agriculture regions (Gaiser et al., 2004; Huang et al., 2003).

While previous studies have investigated the effect of rainfall or warming on model-simulated or satellite-retrieved changes in soil moisture (Dorigo et al., 2012; Trenberth et al., 2014), long-term in situ observation/experiment-based assessments of soil moisture dynamics as affected by climate change are lacking. Moreover, the regional impacts of intense agricultural practices remain poorly understood. Therefore, an investigation of the mechanisms of soil drought in the SANC is crucial for food security and agricultural sustainability, and can provide useful insight into the mitigation of soil drought in semiarid regions. Our research objectives were to (1) investigate the impact of temperature and precipitation on soil moisture using long-term in situ observational climate and soil data collected from the National Agrometeorological Experimental Stations across the SANC during 1981-2010, and (2) to analyze the impacts of agronomic practices (i.e., crop type selection, cropping pattern, fertilizer level, and conservation tillage) on soil drying via five field experiments conducted at the Wuchuan county experimental station from 2008 to 2014 . We used volumetric soil moisture (VSM, \%), water consumption (mm), and water use efficiency (WUE, $\mathrm{g} \mathrm{m}^{-2} \mathrm{~mm}^{-1}$ ) to quantify soil drought in this study.

\section{Materials and methods}

\subsection{Study region}

The SANC (Fig. 1) consists of parts of the Provinces Shanxi, Shaanxi, Heilongjiang, Jilin, Inner Mongolia, Hebei, Ningxia and Gansu (Zhao et al., 2002). Wuchuan County (approximately $40^{\circ} 47^{\prime}-41^{\circ} 23^{\prime} \mathrm{N}$, $\left.110^{\circ} 31^{\prime}-111^{\circ} 52^{\prime} \mathrm{E}\right)$ is located in the SANC with a temperate continental climate (Hu et al., 2014). The average annual precipitation (1960-2014) is approximately $342 \mathrm{~mm}$, and more than $80 \%$ of the total annual precipitation occurs during the crop growing season from April to September. The accumulated temperature above freezing point is $2578{ }^{\circ} \mathrm{C} \mathrm{d}$. The frost-free period is approximately 124 days. The grain fulling stage (June-August) is associated with higher temperatures and precipitation. The soil type is mainly chestnut with high sediment concentrations in the arable layer (Zhang et al., 2015). The cropland in the study area is cultivated rain-fed fields without irrigation. All shortterm experiments were conducted in the Scientific and Observing Experimental Station of the Agro-environment (SOESA) in Wuchuan County during 2008-2014.

\subsection{Data source and experimental design}

To analyze the impact of climate change on soil moisture, daily meteorological data (daily mean temperature and precipitation) during 1981-2010 were collected from 46 climate stations at the National Meteorological Networks of China Meteorological Administration (CMA). These sites are also Agrometeorological Experimental Stations (AESs) that collect long-term observational data of soil moisture, which was measured in the $0-50 \mathrm{~cm}$ soil layer in grasslands, croplands and mono-cropped fields (Table S1). Soil moisture in each field was measured by the gravimetric method in five soil layers $(0-10,10-20$, $20-30,30-40$, and $40-50 \mathrm{~cm}$ ) at the beginning (8th), middle (18th), and end (28th) of each month. The gravimetric method is the only direct method for measuring soil moisture and is indispensable for calibrating instruments used in indirect methods (Reynolds, 1970) (e.g., automated probes). Although the results from the gravimetric method are affected by stones, the organic matter content, etc. in the sample, and unavoidable repeated sampling damages plant roots and changes the soil infiltration characteristics (Reynolds, 1970), the response of soil moisture $(0-50 \mathrm{~cm})$ measured by the gravimetric method to temperature and precipitation can be determined more accurately than that with automatic techniques (Wang et al., 2010; Hu et al., 2014). Moreover, the gravimetric method has been used to measure soil moisture by the AESs since the 1970s (Wang et al., 2010) so long-term (i.e., more than 20 years) soil moisture data can be used to analyze soil moisture changes. We used soil moisture measured in grassland (6 sites) as the control variable. Soil moisture data measured in croplands covered with different crops during 1981-2010 was to analyze the impact of climate change on soil moisture in croplands. Mono-cropped fields include soybean (Glycine $\max$ (Linn.) Merr.) (3 sites), potato (Solanum tuberosum) (13 sites), sugar beet (Beta vulgaris) (3 sites), naked oats (Avena nuda) (3 sites), wheat (Triticum aestivum) (27 sites), and maize (Zea mays L.) fields (27 sites). Soil moisture in the monocropped fields was used to compare the impacts of the different crop types. Detailed information of mono-cropped fields is shown in Table S2.

To explore the effects of agricultural practices on soil moisture, short-term in situ soil moisture data (2008-2014) along with detailed management and yield data were measured in three experiments (see Table 1).

- Continuous-rotation cropping experiment. We designed a control treatment in grassland with No Tillage and No Fertilization (Control-NoT-NoF) and two group Continuous/Rotation cropping treatments in crop fields with Tillage and basal Fertilizer in 2008-2013. The continuous cropping experiment included potato (Solanum tuberosum Cv. Zi Huabai) continuous cropping (P-C-T-bF), millet (Setaria italica (L) Beauv. Cv. 5th Xingu) continuous cropping (M-C-T-bF), rapeseed (Brassica rapa (campestris) L. Cv. 7th Longyou) continuous cropping (Ra-C-T-bF). The crop rotation is the practice of growing a series of dissimilar or different types of crops in the same area in sequenced seasons (Bullock, 1992). The crop rotation experiment in the study included a potato-millet rotation (P-MR-TbF, M-PR-T-bF) and a potato-rapeseed rotation (P-RaR-T-bF, Ra-PRT-bF). Basal fertilizer was applied before sowing with ammonium dihydrogen phosphate (75 kg/ha) and urea ( $90 \mathrm{~kg} / \mathrm{ha})$, and no extra fertilizer was applied during the crop growth period.

- Fertilizer gradient experiment (see Table S3). Potato (Solanum tuberosum Cv. 1th Kexin) continuously cropped with tillage and different fertilizer gradients (P-C-T-gF) were implemented from 2008 to 2010. We designed a control treatment (no fertilizer, P-C- 


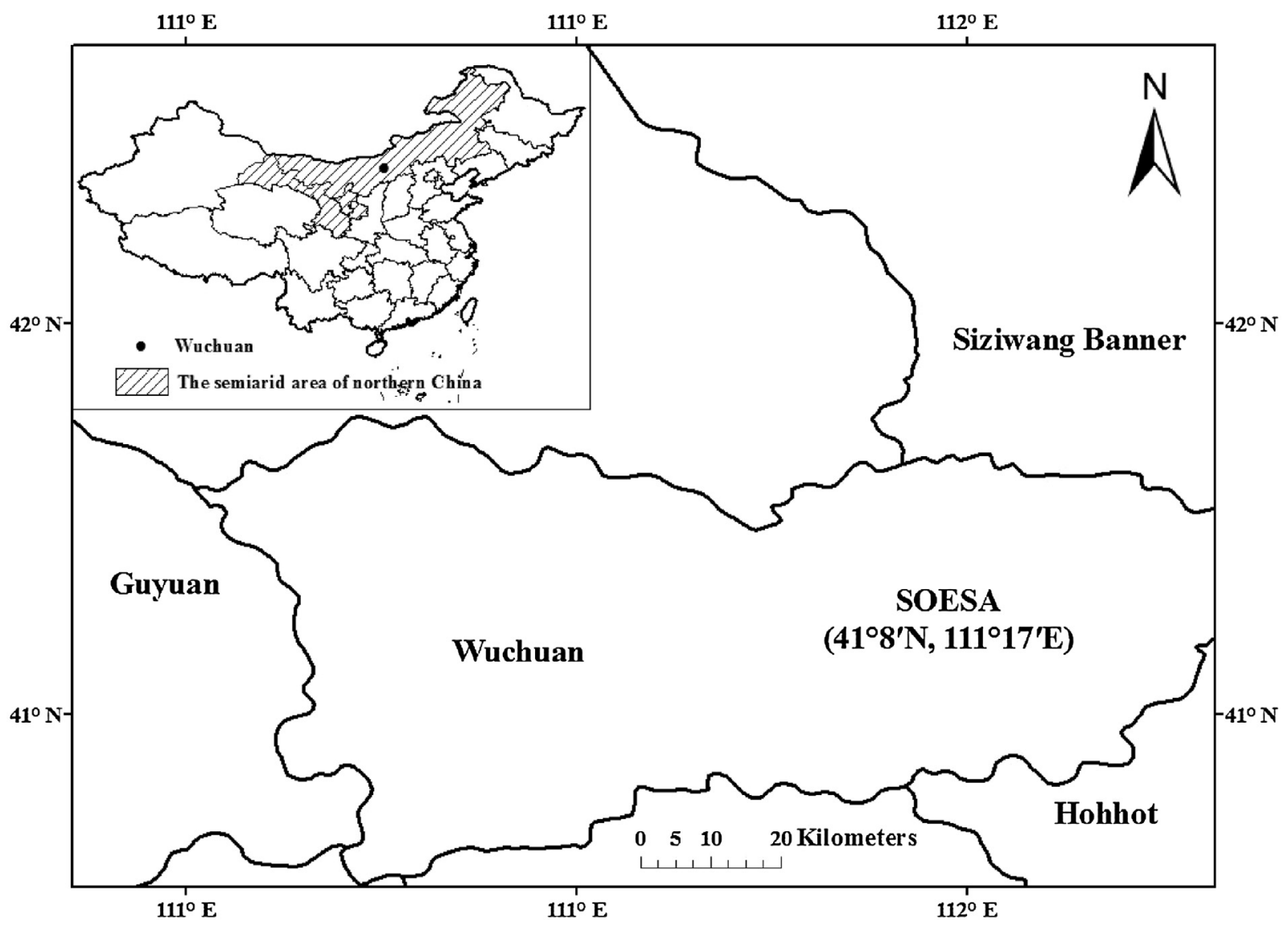

Fig. 1. Map showing the location of the study area in the semiarid area of northern China.

Table 1

The information of three short-term experiments.

\begin{tabular}{|c|c|c|c|}
\hline Experiment & Treatment & Period & Crop \\
\hline Cropping pattern & $\begin{array}{l}\text { Control-NoT-NoF } \\
\text { P-C-T-bF } \\
\text { M-C-T-bF } \\
\text { Ra-C-T-bF } \\
\text { P-MR-T-bF } \\
\text { P-RaR-T-bF } \\
\text { M-R-T-bF } \\
\text { Ra-R-T-bF }\end{array}$ & 2008-2013 & $\begin{array}{l}\text { Potato, Millet, and } \\
\text { Rapeseed }\end{array}$ \\
\hline Fertilizer practices & $\begin{array}{l}\text { P-C-T- } \mathrm{gN}_{0} \mathrm{P}_{0} \\
\text { P-C-T- } \mathrm{gN}_{1} \mathrm{P}_{0.5} \\
\text { P-C-T- } \mathrm{gN}_{2} \mathrm{P}_{1} \\
\text { P-C-T- } \mathrm{gN}_{3} \mathrm{P}_{1.5} \\
\text { P-C-T- } \mathrm{gN}_{4} \mathrm{P}_{2} \\
\text { P-C-T- } \mathrm{gN}_{1} \mathrm{P}_{1} \\
\text { P-C-T- } \mathrm{gN}_{2} \mathrm{P}_{2} \\
\text { P-C-T- } \mathrm{gN}_{3} \mathrm{P}_{3} \\
\text { P-C-T- } \mathrm{gN}_{4} \mathrm{P}_{4}\end{array}$ & $2008-2010$ & Potato \\
\hline Tillage practices & $\begin{array}{l}\text { Control-Fallow } \\
\text { W-T-NoF } \\
\text { W-NoT-NoF }\end{array}$ & 2014 & Spring wheat \\
\hline
\end{tabular}

$\mathrm{T}-\mathrm{gN}_{0} \mathrm{P}_{0}$ ) and four fertilizer gradients treatments with different carbon and nitrogen ratios $(\mathrm{N}: \mathrm{P}=2: 1$ and $\mathrm{N}: \mathrm{P}=1: 1)$. The four fertilizer gradients included low fertilizer level (P-C-T-gN $\mathrm{P}_{0.5}$ and P-C-T- $\mathrm{gN}_{1} \mathrm{P}_{1}$ ), medium fertilizer level (P-C-T-gN ${ }_{2} \mathrm{P}_{1}$ and P-C-T$\mathrm{gN}_{2} \mathrm{P}_{2}$ ), high fertilizer level (P-C-T- $\mathrm{gN}_{3} \mathrm{P}_{1.5}$ and P-C-T- $\mathrm{gN}_{3} \mathrm{P}_{3}$ ), and extremely high fertilizer level (P-C-T-gN ${ }_{4} \mathrm{P}_{2}$ and P-C-T-gN $\mathrm{P}_{4} \mathrm{P}_{4}$ ).

- Tillage experiment. Additional experiments were conducted in spring wheat fields to examine the effect of different tillage treatments on soil moisture in 2014, including Control experiment in a fallow field (Control-Fallow), Tillage $(0-18 \mathrm{~cm})$ before sowing in a wheat field without fertilizer (W-T-NoF), and No-tillage before sowing in a wheat field without fertilizer (W-NoT-NoF). Tillage is the agricultural preparation of soil by mechanical agitation of various types, such as digging, stirring, and overturning (Azooz et al., 1997). The tillage experiment in the study adopted minimum tillage which disturbed soil layer less than $18 \mathrm{~cm}$. No-tillage is a way of growing crops or pasture from year to year without disturbing the soil through tillage (Blanco-Canqui et al., 2009). Soil moisture was measured at 10 critical growth stages of the spring wheat.

Each treatment was replicated three times in a randomized complete block design. Each plot was $6 \times 10 \mathrm{~m}$, with 3 control plots, 9 continuous cropping plots, 12 crop rotation plots, 27 fertilizer gradient plots, and 9 tillage plots. A detailed description of the sample data is shown in Table S4. The row spacing was $0.5 \mathrm{~m}$. The crop density of potato, millet, rapeseed, and spring wheat was 60,000 plants/ha, $1,200,000$ plants/ha, and 1,600,000 plants/ha, 1,200,000 plants/ha, respectively. All experiments were conducted in a 4.0 ha area. Soil physical and chemical properties were assumed to be spatially homogeneous. The $\mathrm{pH}$ was 8.24-8.27. The total nitrogen, available phosphorus, available potassium, and organic matter contents in the $0-100 \mathrm{~cm}$ soil layer were $1.09 \mathrm{~g} / \mathrm{kg}, 4.96 \mathrm{mg} / \mathrm{kg}, 105.27 \mathrm{mg} / \mathrm{kg}$, and $1.34 \%$, respectively. The vertical distribution of these chemical constituents is shown in Table S5. During 2008-2014, the crops were sown in mid-May, and harvested in mid-September. The crop yield was estimated by the oven-drying method $\left(105^{\circ} \mathrm{C}\right.$ for $30 \mathrm{~min}$, then $80^{\circ} \mathrm{C}$ for $8 \mathrm{~h}$ ) for each plot.

\subsection{Analysis of long-term measurements}

To examine the impact of climate change on soil water content, a 
panel regression model (PRM) was used to investigate the relationship between climatic factors and the VSM at 46 stations across the study area. This method relies on the information about multiple impact factors and can predict crop responses to climate change (Lobell and Burke, 2010; Tao et al., 2014), while avoiding the confounding effects of highly correlated climate variables. Our analyses showed high correlations between soil moisture and the annual mean temperature and precipitation. Three PRMs with different predictors were estimated to quantify the uncertainties in estimating the VSM responses to major climate variables (Tao et al., 2014).

$V S M_{t}=\alpha_{0}+\alpha_{t} t+\alpha_{T} T_{t}+\varepsilon_{t}$,

$V S M_{t}=\alpha_{0}+\alpha_{t} t+\alpha_{T} T_{t}+\alpha_{P} P_{t}+\varepsilon_{t}$

$V S M_{t}=\alpha_{0}+\alpha_{t} t+\alpha_{P} P_{t}+\varepsilon_{t}$

where $V S M_{t}$ is the average VSM during the growth season at SOESA in year $t$. $T_{t}$ and $P_{t}$ represent the average temperature $\left({ }^{\circ} \mathrm{C}\right)$ and precipitation (mm) during the growth season at SOESA in year $t, \alpha_{0}$ represents the intercept. $\alpha_{t}$ represents the linear time trend of the observed VSMs, mainly due to non-climatic trends that include improvements of cultivars, technology, management, and policy during the study period. The $\alpha_{T}$, represents different estimates of the sensitivity of the VSM to the average temperature. The $\alpha_{P}$, represents different estimates of the sensitivity of the VSM to precipitation during the growing season. $\varepsilon_{t}$ is an error term.

The impact of a climate variable on soil moisture (expressed as a percentage of the actual mean VSM) was estimated by multiplying the sensitivity of soil moisture to the climate variable with changes of the climate variable during the study period. The impact of a single factor (i.e., the mean temperature or precipitation) on soil moisture were the average impacts of the climate variable in all regression models. The joint impacts of climate change on soil moisture from 1981 to 2010 were computed by summing the impacts of mean temperature and precipitation on soil moisture during the study period. All statistical analyses were performed with SPSS 13.0. Statistical significance was assessed with a two-tailed $t$-test. The significance (at $p<0.05$ ) of the differences for each crop and period were determined with a one-way Analysis of Variance (ANOVA).

\subsection{Analysis of short-term experiment measurements}

To quantify the effect of agricultural practice on soil water, the total soil water storage (SWS, mm) and volumetric soil moisture (VSM, \%) in all experiments were calculated using the method of Hu et al. (2014). In each soil layer, the SWS was estimated as the multiple of the soil bulk density $\left(\mathrm{g} \mathrm{cm}^{-3}\right)$, the gravimetric soil water content $(\mathrm{g} / \mathrm{g} \%)$, and the soil layer thickness $(\mathrm{cm})$. The total SWS was the sum of the SWS in each soil layer. The water use efficiency (WUE, $\mathrm{g} \mathrm{m}^{-2} \mathrm{~mm}^{-1}$ ) was defined as the ratio of the crop yield $\left(\mathrm{g} \mathrm{m}^{-2}\right)$ to the actual evapotranspiration $\left(\mathrm{ET}_{\mathrm{a}}, \mathrm{mm}\right)$ during the growth season. $\mathrm{ET}_{\mathrm{a}}$ is defined as the actual water consumption ( $\mathrm{mm}$ ) during the growing season, and it was computed by the soil water balance equation (Xiao et al., 2013; Zhang et al., 2015).

\section{Results}

\subsection{Observed climate change and soil moisture during 1981-2010}

From 1981 to 2010, a significant warming-drying trend during the crop growing season from April to September was detected in the SANC (Fig. 2). The average temperature (Tmean) during the crop growth season was $17.0 \pm 0.15^{\circ} \mathrm{C}$ (avg. \pm 2 std. dev.) (Table S6). Higher temperatures occurred mainly west and east of the SANC (Fig. 2a). All stations showed a significant $(p<0.05)$ positive Tmean trend of $0.06{ }^{\circ} \mathrm{C}$ per year across the SANC (Table S6). The average precipitation in the crop growth season was $256.9 \pm 10.0 \mathrm{~mm}$, with a mean negative rate of $1.65 \mathrm{~mm}$ per year $(p<0.05)$ (Table S6). Less precipitation (from 130 to $230 \mathrm{~mm}$ ) was detected in the western SANC (Fig. 2c and d). The average VSM during the crop growth season was $17.3 \pm 0.20 \%$, with a significant negative trend of $0.16 \%$ per year across the SANC (Table S6). A severe drying trend in soil moisture mainly occurred in the eastern SANC from 1981 to 2010 (Fig. 2f).

\subsection{The impact of climate change on soil moisture}

The multiple linear regression analyses per station were conducted to show the spatio-temporal impact of climate change on soil moisture. The results indicated that the VSM was negatively correlated with T mean, but positively correlated with precipitation during the crop growth season (Table S7). The multiple linear regressions could explain $15-62 \%$ of the variation $(p<0.05, \mathrm{n}=22-30)$ in the VSM at 46 stations (Table S7). For each $1{ }^{\circ} \mathrm{C}$ increase in Tmean, VSM decreased up to $5.0 \%$ (Fig. S1a) on average of 46 stations. Higher sensitivities were observed in the eastern SANC. In contrast, for a precipitation increase of $1 \mathrm{~mm}$, VSM increased up to $0.035 \%$ (Fig. S1b) on average. Lower impacts were detected in the middle of the SANC, and the highest sensitivities mainly occurred in the eastern SANC (Fig. S1b). The contribution of climate change to the VSM (Fig. S1d-f) also has been evaluated. The contribution of Tmean to the average VSM was from $-3 \%$ to $-33 \%$ during $1981-2010$ across the entire study area (Fig. S1d). The contribution of precipitation to the average VSM was $-7 \%$ to $4 \%$, and a negative contribution occurred in most regions of the SANC (Fig. S1e). From 1981 to 2010, the average combined contribution of climate change (Tmean and precipitation) at 46 stations to the average VSM was $-11.2 \%$, and it became weaker from the eastern to the western SANC (Fig. S1f).

\subsection{The impact of agricultural practices on soil moisture}

\subsubsection{The impact of crop type on soil moisture}

A further analysis of VSM was carried out by calculating differences between different crop type fields from 1981 to 2010 in the SANC (Table S2). The average VSM from 1981 to 2010 was $9.1 \%$ in grassland, and a much higher VSM $(p<0.05)$ of $56.0-124.2 \%$ was seen in all mono-cropped fields (Table S2). The negative trend of VSM in grassland was $-0.06 \%$ per year, and this trend was not significant. However, VSM had significant negative trends $(p<0.05)$ for potato, maize, soybean, and sugar beet fields (Table S2), which indicated that VSM in these fields showed the greatest decrease of all crop fields. These results indicated that soil drought may be aggravated if the water-expensive crop area is expanded.

\subsubsection{The impact of the cropping pattern on soil moisture}

The cropping pattern treatments in SOESA from 2008 to 2013 showed that VSM $(0-100 \mathrm{~cm}$ soil depth) in all of the continuous and crop rotation treatments decreased remarkably from the tuber-initiation stage to the mature stage (60 days after sowing to maturity) (Fig. 3). The mean VSM in the crop rotation treatments was lower than in the continuous cropping treatments (Fig. 4a). VSM in the P-MR-T-bF and P-RaR-T-bF treatments was $15.4 \%$ and $33.9 \%$ lower than that in the P-C-T-bF treatment, and VSM in the M-PR-T-bF treatment was $14.2 \%$ lower than that in the treatment M-C-T-bF; VSM in the Ra-PR-T-bF treatment also showed $15.3 \%$ of decline compared to that in the Ra-C-TbF treatment (Fig. 4a).

The water consumption in cropping pattern treatments was significantly higher than those in the Control-NoT-NoF treatment (Fig. 4b). Compared to that in the Control-NoT-NoF treatment, the significant rise $(p<0.05)$ in the continuous treatments (P-C-T-bF, MC-T-bF, Ra-C-T-bF) was $12.4 \%, 16.3 \%$, and $23.8 \%$, respectively (Fig. 4b). The significant rise $(p<0.05)$ in the rotation treatments (P-MR-T-bF, P-RaR-T-bF, M-PR-T-bF, Ra-PR-T-bF) was 21.3\%, 24.6\%, $27.1 \%$, and $36.4 \%$, respectively (Fig. $4 \mathrm{~b}$ ). Moreover, the differences in water consumption between the rotation and the continuous cropping 

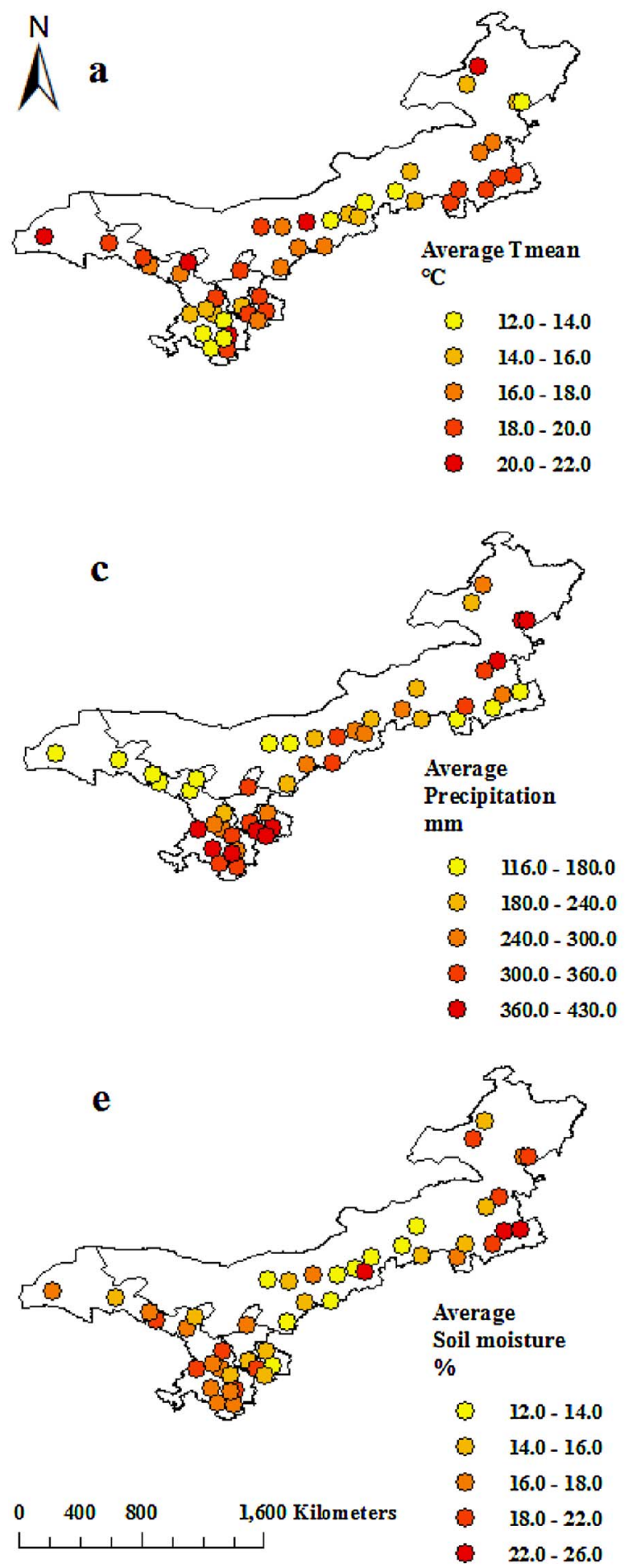
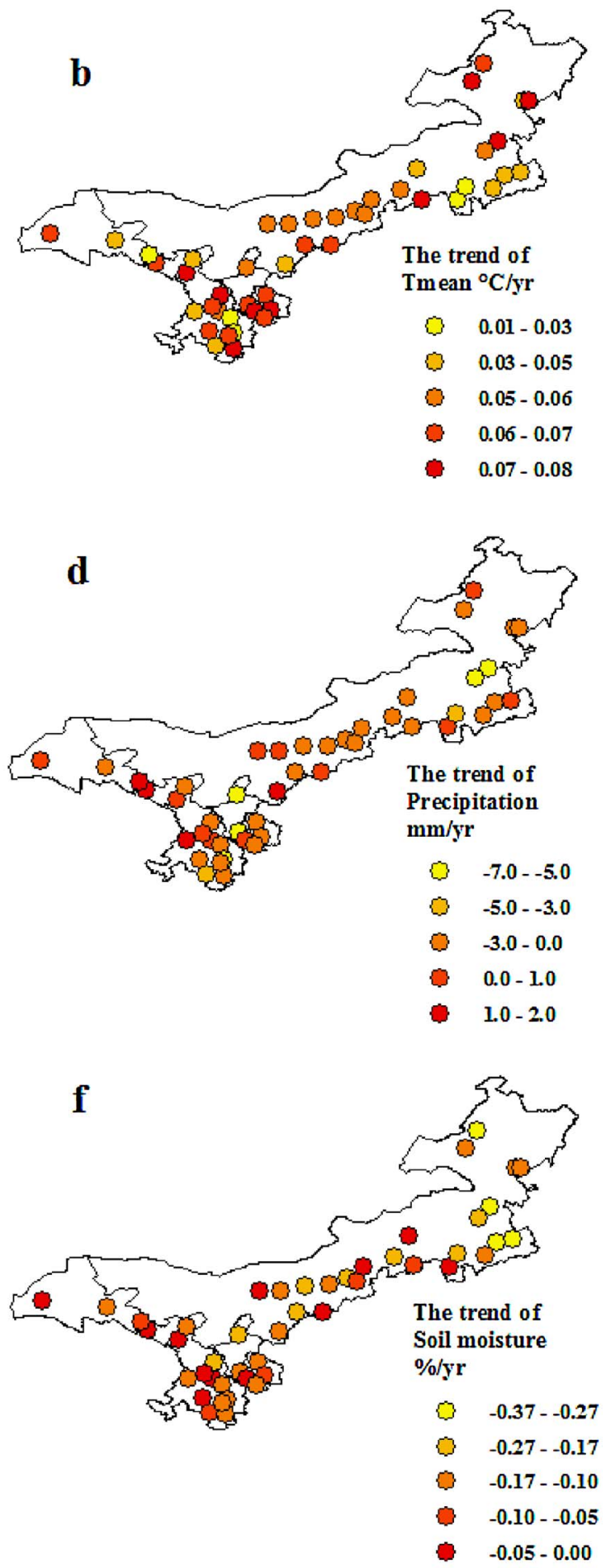

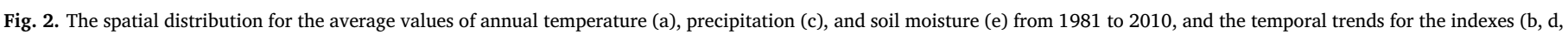
and f) during same period across the semiarid area of northern China (SANC).

treatments were significant $(p<0.05)$. These results indicate that farming consumes more soil moisture compared to grasslands, and crop rotation most greatly aggravates soil drought.

However, crop rotation increased the water use efficiency compared to continuous cropping (Fig. 4c). Compared to those in the continuous treatments, the significant rise $(p<0.05)$ of the WUE was $23.6-34.3 \%$ for potato, $58.3 \%$ for millet, and $49.5 \%$ for rapeseed on average, respectively (Fig. 4c).

\subsubsection{The impact of fertilizer practices on soil moisture}

The fertilizer treatments in SOESA from 2008 to 2010 showed that VSM in the $0-100 \mathrm{~mm}$ soil layer decreased significantly with increased fertilizer input (Fig. 5). During the entire growth period, the mean VSM in the P-C-T- $\mathrm{gN}_{0} \mathrm{P}_{0}$ treatment from 2008 to 2010 was $14.5 \%$ (Fig. 5). Compared to the P-C-T- $-\mathrm{gN}_{0} \mathrm{P}_{0}$ treatment, VSM in the $\mathrm{N}: \mathrm{P}=2: 1$ fertilizer gradient treatments (from low to extremely high fertilizer) decreased by $7.3 \%$ ( $p>0.05), 11.3 \%(p<0.05), 16.2 \%(p<0.05)$, and $19.6 \%(p<0.05)$ (Fig. 5a), and VSM in the N:P $=1: 1$ fertilizer gradient treatments decreased by $2.0 \%(p>0.05), 11.2 \%(p<0.05)$, 


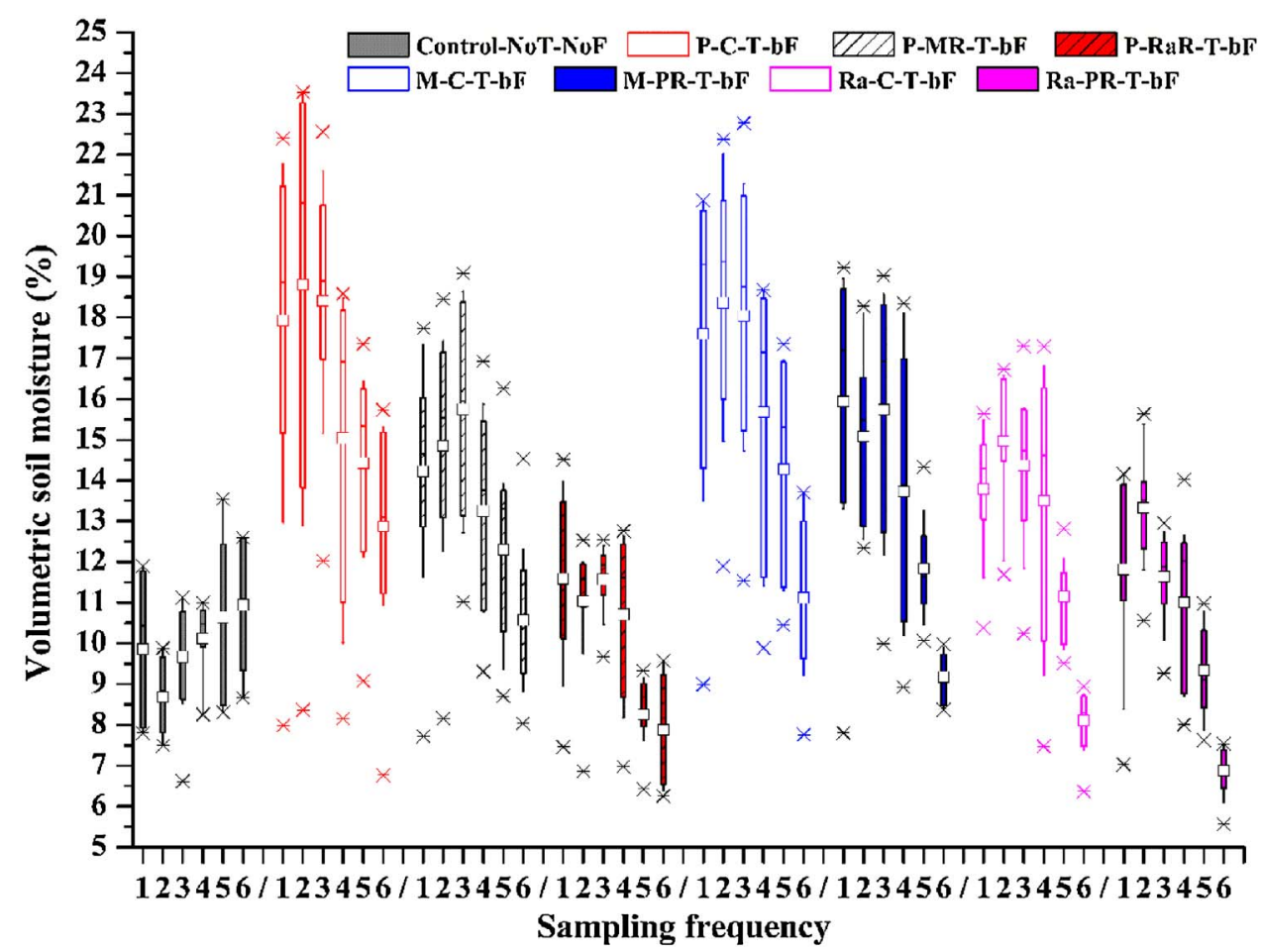

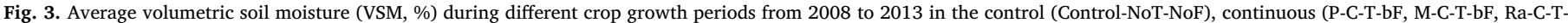

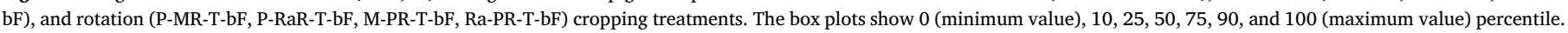

$17.7 \%(p<0.05)$, and $49.6 \%(p<0.05)$, respectively (Fig. 5b). The results indicate that VSM was significantly reduced as the fertilizer input rose, and high and extremely high fertilizer aggravated soil moisture drying.

Table 2 shows that the water consumption increased as the fertilizer input increased. During the entire growth period, the mean water consumption in the P-C-T- $-\mathrm{gN}_{0} \mathrm{P}_{0}$ treatment from 2008 to 2010 was $211.3 \mathrm{~mm}$ (Table 2). The increase in the water consumption for the $\mathrm{N}: \mathrm{P}=2: 1$ fertilizer gradient treatments were $10.6 \%(p>0.05)$, $23.8 \%(p<0.05), 40.1 \% \quad(p<0.05)$, and $46.9 \% \quad(p<0.05)$

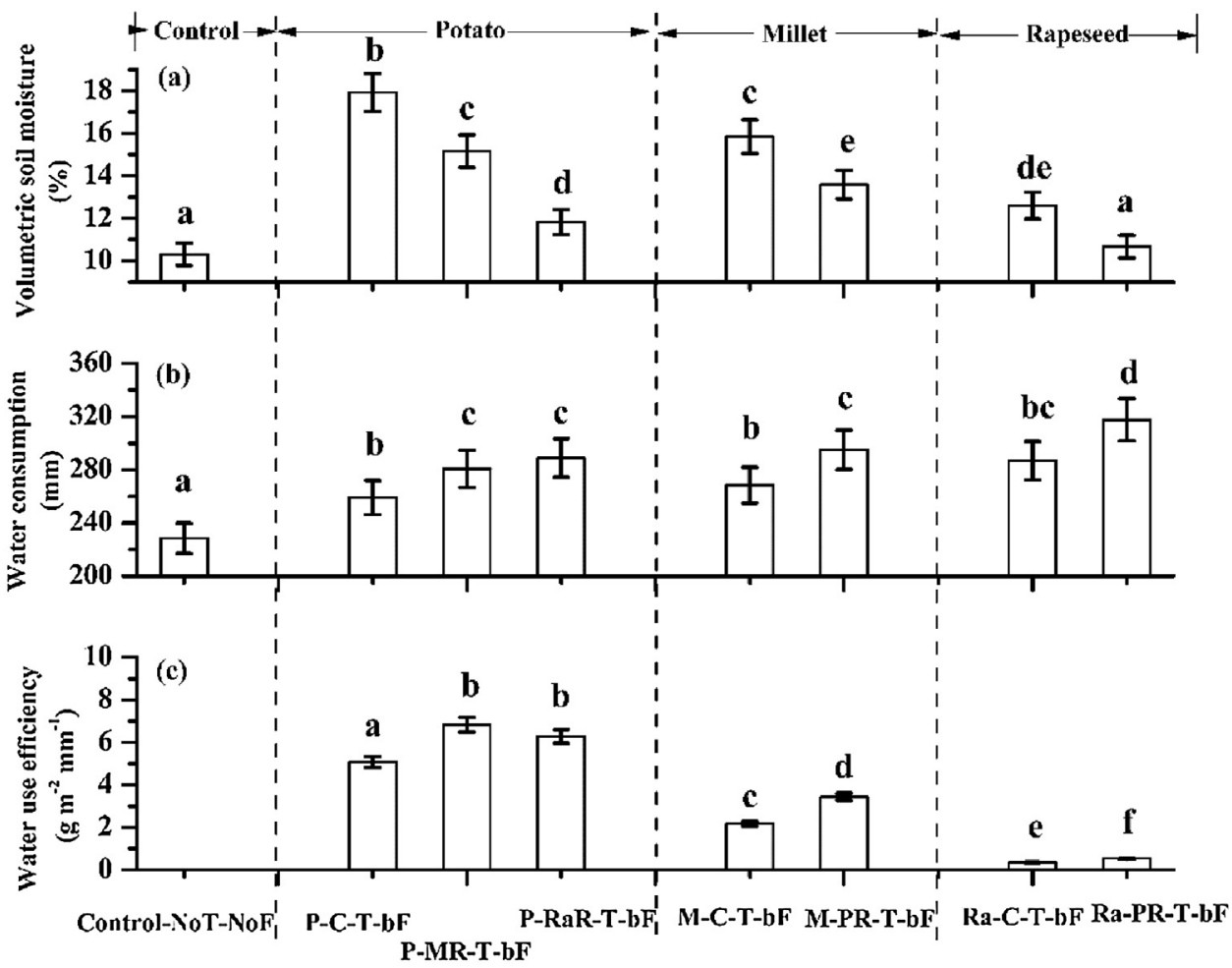

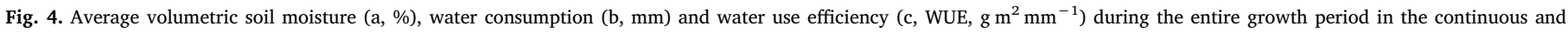

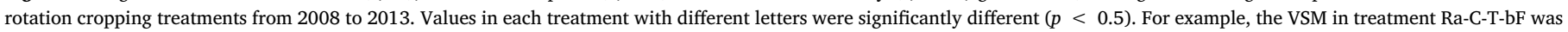
significantly different from Control-No-T-NoF, but Ra-C-T-bF was not different from P-RaR-T-bF and M-PR-T-bF. 


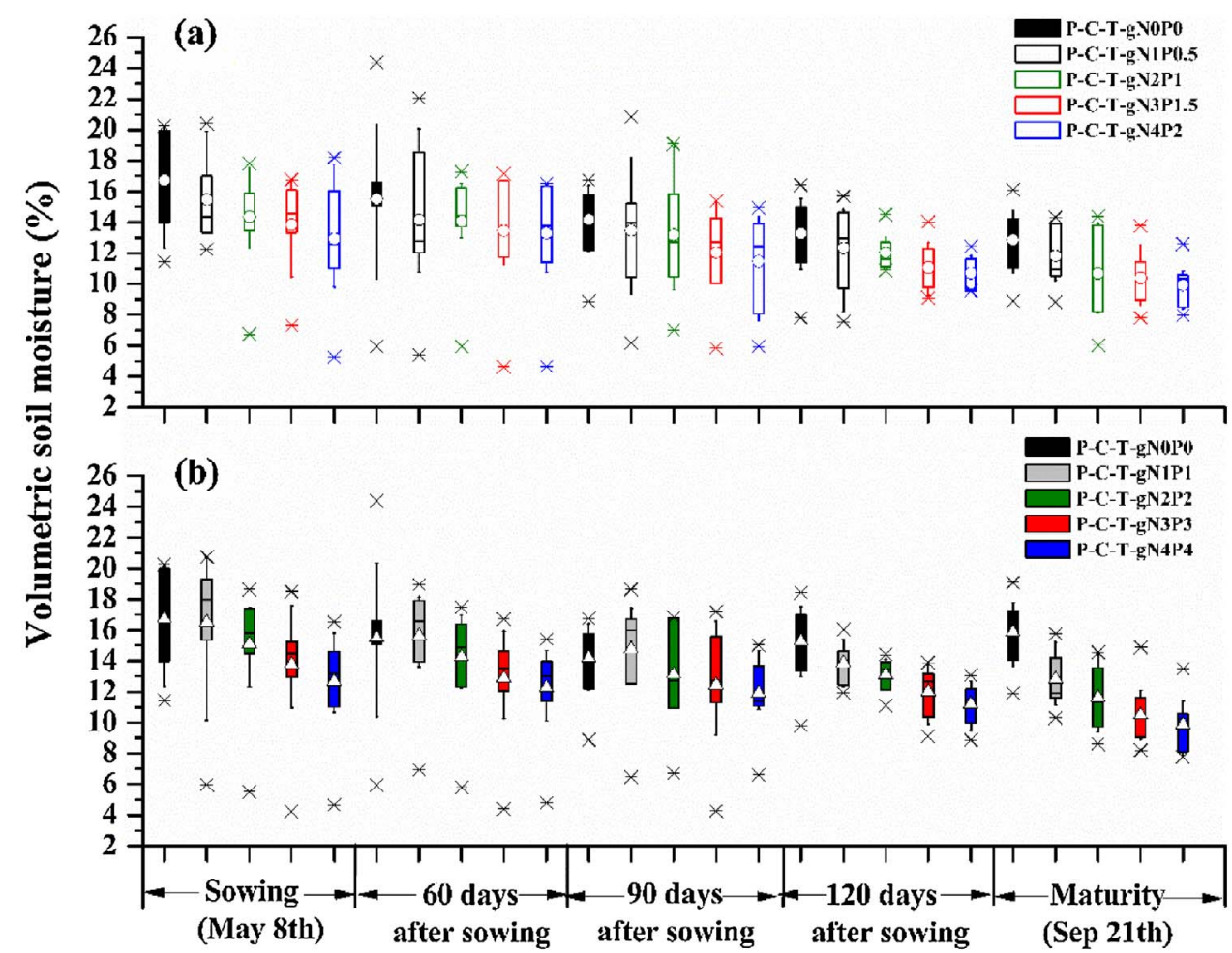

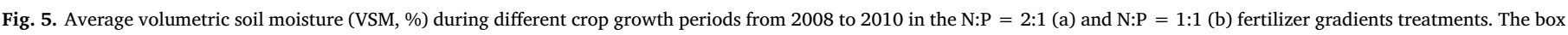
plots show 0 (minimum value), 10, 25, 50, 75, 90, and 100 (maximum value) percentile.

(Table 2) and for the $\mathrm{N}: \mathrm{P}=2: 1$ fertilizer gradient treatments they were 6.2\% ( $p>0.05$ ), $16.5 \%$ ( $p<0.05$ ), $25.4 \%(p<0.05$ ), and $35.7 \%$ $(p<0.05)$ (Table 2). The results suggest a positive effect of fertilizer on water consumption.

The low fertilizer treatments (P-C-T- $\mathrm{gN}_{1} \mathrm{P}_{0.5}, \mathrm{P}-\mathrm{C}-\mathrm{T}-\mathrm{gN}_{1} \mathrm{P}_{1}$ ) showed a significant increase in WUE compared to the P-C-T- $\mathrm{gN}_{0} \mathrm{P}_{0}$ treatment from 2008 to 2010, while the WUE decreased by $14.6-27.9 \%$ and 21.6-35.3\% in the high (P-C-T- $\mathrm{gN}_{3} \mathrm{P}_{1.5}$ and P-C-T- $\mathrm{gN}_{3} \mathrm{P}_{3}$ ) and extreme high (P-C-T- $\mathrm{gN}_{4} \mathrm{P}_{2}$ and P-C-T- $\mathrm{gN}_{4} \mathrm{P}_{4}$ ) fertilizer treatments, respectively (Table 2). The results indicate that low and medium fertilizer can stimulate the WUE, while excessive fertilizer leads to a decline in the WUE.

\subsubsection{The impact of tillage on soil moisture}

The tillage treatments in SOESA in 2014 showed that VSM in the 0-100 mm soil layer in a tilled field was lower than that in a no-tillage field (Fig. 6). During the seedling (Fig. 6a), anthesis (Fig. 6b), and mature stages (Fig. 6c), compared to the Control-Fellow treatment, the decline of VSM in the tillage treatments was $20.7 \%(p<0.05), 36.7 \%$ $(p<0.05)$, and $32.6 \%(p<0.05)$, respectively, and the decline of VSM in the no-tillage treatments was $3.3 \%(p>0.05), 3.1 \%$ ( $p>0.05)$, and 1.5\% ( $p>0.05)$, respectively. Both the tillage and no-tillage treatments decreased VSM from the heading stage to the filling stage (approximately $60-110$ days after sowing) by $30.4 \%$ $(p<0.05)$ and $19.2 \%(p<0.05)$ compared to the Control-Fallow treatment (Fig. 6d). The results suggest that a fallow field has the highest water storage capacity, while a tilled field has the lowest soil moisture.

Table 3 shows that the water consumption in the tillage and notillage treatments was $39.6 \%$ and $29.3 \%$, respectively, $(p<0.05)$ higher on average than that in the Control-Fallow treatment. A fallow field can restore soil moisture and no-tillage consumes less water than tillage. However, the difference of the WUE between no-tillage and tillage was non-significant (Table 3).

Table 2

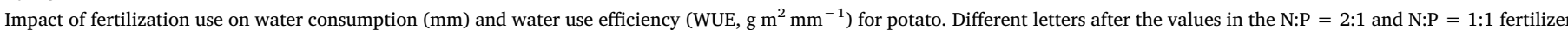
treatments indicate significant differences between the values at the level of $p=0.05$.

\begin{tabular}{|c|c|c|c|c|c|c|c|c|c|c|}
\hline \multirow[t]{2}{*}{ Fertilizer gradient } & \multirow[t]{2}{*}{ Treatment } & \multicolumn{3}{|l|}{2008} & \multicolumn{3}{|l|}{2009} & \multicolumn{3}{|l|}{2010} \\
\hline & & $\begin{array}{l}\text { Water consumption } \\
\mathrm{mm}\end{array}$ & $\begin{array}{l}\text { Yield } \\
\mathrm{kg} \mathrm{ha}^{-1}\end{array}$ & $\begin{array}{l}\text { WUE } \\
\mathrm{g} \mathrm{mm}^{-2} \mathrm{~m}^{-1}\end{array}$ & $\begin{array}{l}\text { Water consumption } \\
\mathrm{mm}\end{array}$ & $\begin{array}{l}\text { Yield } \\
\mathrm{kg} \mathrm{ha}^{-1}\end{array}$ & $\begin{array}{l}\text { WUE } \\
\mathrm{g} \mathrm{mm}^{-2} \mathrm{~m}^{-1}\end{array}$ & $\begin{array}{l}\text { Water consumption } \\
\mathrm{mm}\end{array}$ & $\begin{array}{l}\text { Yield } \\
\mathrm{kg} \mathrm{ha}^{-1}\end{array}$ & $\begin{array}{l}\text { WUE } \\
\mathrm{g} \mathrm{mm}^{-2} \mathrm{~m}^{-1}\end{array}$ \\
\hline No fertilizer & P-C-T- $\mathrm{gN}_{0} \mathrm{P}_{0}$ & $260.3(11.56) \mathrm{a}$ & 10920 & $4.20(0.26) \mathrm{a}$ & $221.5(8.73) \mathrm{a}$ & 5235 & $2.36(0.01) \mathrm{a}$ & $152.0(4.20) \mathrm{a}$ & 5135 & $3.38(0.05) \mathrm{a}$ \\
\hline Low & P-C-T-gN ${ }_{1} P_{0.5}$ & $296.9(8.93) \mathrm{b}$ & 14600 & $4.92(0.11) b$ & $220.4(15.23) \mathrm{a}$ & 5570 & $2.53(0.11) \mathrm{a}$ & 183.7 (13.77) b & 6421 & $3.50(0.21) \mathrm{a}$ \\
\hline Medium & P-C-T-gN ${ }_{2} \mathrm{P}_{1}$ & $322.0(10.56) \mathrm{c}$ & 13871 & $4.31(0.25) \mathrm{a}$ & $261.6(9.78) \mathrm{b}$ & 6434 & $2.46(0.15) \mathrm{a}$ & $201.2(11.84) \mathrm{b}$ & 6801 & $3.38(0.19) \mathrm{b}$ \\
\hline High & P-C-T-gN ${ }_{3} \mathrm{P}_{1.5}$ & $358.9(18.00) \mathrm{cd}$ & 11130 & $3.10(0.10) \mathrm{b}$ & $290.7(10.00) \mathrm{c}$ & 5703 & $1.96(0.23) \mathrm{b}$ & $250.9(15.35) \mathrm{c}$ & 5294 & $2.11(0.13) \mathrm{c}$ \\
\hline Extreme high & P-C-T-gN ${ }_{4} \mathrm{P}_{2}$ & $361.0(15.69) \mathrm{d}$ & 10270 & $2.84(0.22) \mathrm{c}$ & $304.8(13.45) \mathrm{c}$ & 5460 & $1.79(0.28) b$ & $265.4(9.87) \mathrm{c}$ & 4780 & $1.80(0.07) \mathrm{d}$ \\
\hline Low & P-C-T- $\mathrm{gN}_{1} \mathrm{P}_{1}$ & $282.6(9.28) \mathrm{a}$ & 13330 & $4.72(0.04) \mathrm{a}$ & $230.3(9.45) \mathrm{a}$ & 5625 & $2.44(0.01) \mathrm{a}$ & $160.2(6.75) \mathrm{a}$ & 6407 & $4.00(0.04) \mathrm{a}$ \\
\hline Medium & P-C-T- $\mathrm{gN}_{2} \mathrm{P}_{2}$ & $316.8(11.56) \mathrm{b}$ & 13625 & $4.30(0.03) \mathrm{a}$ & 237.5 (11.06) a & 5955 & $2.51(0.02) \mathrm{a}$ & $184.2(8.46) \mathrm{b}$ & 6010 & $3.26(0.02) b$ \\
\hline High & P-C-T- $\mathrm{gN}_{3} \mathrm{P}_{3}$ & $350.5(16.70) \mathrm{c}$ & 11670 & $3.33(0.05) \mathrm{b}$ & $242.3(6.70) \mathrm{b}$ & 5035 & $2.08(0.04) b$ & $202.1(10.70) \mathrm{bc}$ & 6215 & $3.08(0.03) b$ \\
\hline Extreme high & P-C-T-gN ${ }_{4} \mathrm{P}_{4}$ & $359.2(12.80) \mathrm{c}$ & 11200 & $3.12(0.04) \mathrm{b}$ & $265.7(12.86) \mathrm{c}$ & 5070 & $1.91(0.03) \mathrm{b}$ & $235.3(8.60) \mathrm{c}$ & 6490 & $2.76(0.02) \mathrm{c}$ \\
\hline
\end{tabular}



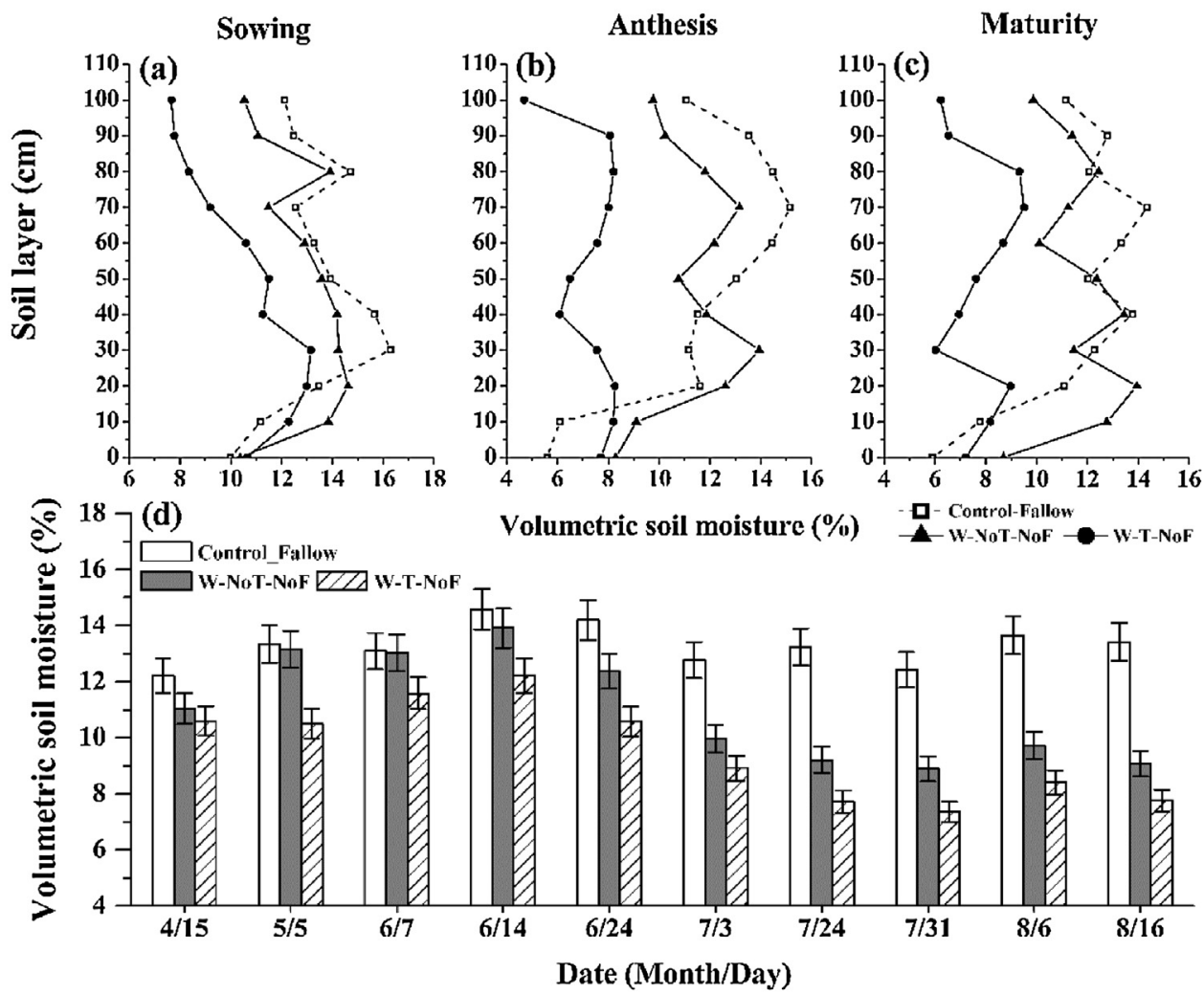

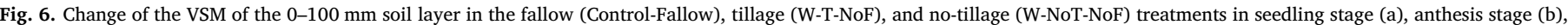
mature stage (c), and the mean VSM of the $0-100 \mathrm{~mm}$ after sowing (d) for spring wheat in 2014 .

\section{Discussion}

\subsection{Impacts of climate change on soil moisture}

We found that soil droughts occurred across the semiarid area of northern China and seriously threatened agricultural ecosystems in past decades, which agrees with the results of Leng et al. (2015). Climate change leads to higher temperatures and may also change the regional precipitation levels and its temporal variability and water flow dynamics (Holsten et al., 2009; Piao et al., 2010) and finally may lead to changes in potential evapotranspiration and crop water demand, decreasing soil moisture and aggravating soil drought (Thomas, 2000; Chen et al., 2012). Our results from long-term soil moisture observational data are consistent with this conclusion. However, we found the highest temperature and lowest precipitation in the western regions was not accompanied by the lowest soil moisture (Fig. 2a, c and e), suggesting that climate change is not the primary factor for soil drought aggravation. The soil physical properties (i.e., soil type, porosity, density, permeability, etc.) have the potential to impact soil moisture (Cosby et al., 1984). The percent value of the silt, sand, and clay content is the key factor that determines soil physical properties and soil moisture (Cosby et al., 1984). Soils with a high silt/sand content such as histosols or fluvisols are more susceptible to absolute changes than loamy soils (Holsten et al., 2009), which can explain the generally higher levels of soil water in more loamy soils and the slow capillary transportation of water in sandy soils. For example, soil moisture in the Ewenk grassland (Loam) was higher than in the Xilin Hot (Silty loam) and Uxin Ju (Sandy) regions (see Table S1). Current agricultural activities has the potential to exacerbate soil drought by destroying the soil physical structure and reducing the field soil moisture (Rosenzweig et al., 2008), and the considerable contribution of agricultural practices to the decline in soil moisture may be less straightforward.

\subsection{Impact of agricultural practices on soil moisture}

This study suggests that agricultural practices such as expanding the water-expensive crop area, rotation cropping, tillage practices, and high fertilizer application may aggravate soil drought. The results of our study are consistent with the studies by Özkan and Gökbulak, (2017), Liu et al. (2015), and Gaiser et al. (2004). For example, a change in vegetation from forest to herbaceous had a significant effect on soil moisture, temperature and soil water chemistry (Özkan and Gökbulak, 2017). On the one hand, the greatest changes in soil moisture occurred after a change in vegetation because of an alteration of solar radiation on the soil surface and transpiration (Holsten et al., 2009). On the other hand, the biochemical and physical properties of the soil changed remarkably due to different vegetation root microenvironments and

Table 3

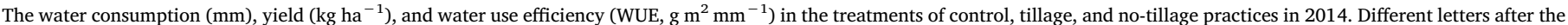
values indicate significant differences between the values at the level of $p=0.05$.

\begin{tabular}{|c|c|c|c|c|c|c|}
\hline Tillage practices & $\begin{array}{l}\text { SWS at sowing } \\
(\mathrm{mm})\end{array}$ & $\begin{array}{l}\text { SWS at harvest } \\
(\mathrm{mm})\end{array}$ & $\begin{array}{l}\text { precipitation } \\
(\mathrm{mm})\end{array}$ & $\begin{array}{l}\text { Water consumption } \\
(\mathrm{mm})\end{array}$ & $\begin{array}{l}\text { Yield } \\
\left(\mathrm{kg} \mathrm{ha}^{-1}\right)\end{array}$ & $\begin{array}{l}\text { WUE } \\
\left(\mathrm{g} \mathrm{m}^{2} \mathrm{~mm}^{-1}\right)\end{array}$ \\
\hline Control-Fallow & 183.2 & 204.2 & 181.2 & $160.2^{\mathrm{a}}(16.5)$ & - & - \\
\hline W-T-NoF & 158.7 & 116.3 & 181.2 & $223.7^{\mathrm{c}}(12.4)$ & 1126.6 & $0.50^{\mathrm{a}}(0.03)$ \\
\hline W-NoT-NoF & 161.7 & 135.7 & 181.2 & $207.2^{\mathrm{b}}(10.5)$ & 1018.8 & $0.49^{\mathrm{a}}(0.05)$ \\
\hline
\end{tabular}


organic content, which would change the soil water holding capacity (Özkan and Gökbulak, 2017). In the SANC, the expansion of the potato and maize cultivation area since 1990 (Zhang et al., 2015; Liu et al., 2015) as a result of population growth and the demand for larger food resources would intensify soil drying and therefore threaten the agricultural ecosystems.

Moderate fertilizer use enhances microbial activity, increases soil organic matter, improves the soil structure, and increases the soil water-holding capacity and permeability, which finally increase soil moisture content (Gaiser et al., 2004; Huang et al., 2003). However, excessive fertilizer increases transpiration because of more vigorous crop growth (Gaiser et al., 2004; Huang et al., 2003), leading to a decline in soil moisture. Worse, excessive fertilizer impedes the absorption of water so that a crop tends to wilt and die, thus increasing the exposed soil area and soil evaporation, which depletes soil moisture and leads to soil drought in rain-fed agriculture regions. In China, the fertilizer use rate is more than twice the world average (World Bank, 2006; Tian et al., 2012). The yield per hectare of all crops has increased, but the fertilizer use efficiency (yield/fertilizer amount) has dramatically decreased for the three primary crops from 1961 to 1998 (Tong et al., 2003). This study revealed that high fertilizer use may exacerbate drought, as well as agricultural ecosystems deterioration in rainfed regions and the unnecessary expenditure for fertilizer causes an economic loss, which highlights the need for fertilizer optimization from a hydrological perspective.

Because undisturbed soil has lower soil porosity and a greater soil bulk density, no-tillage fields have lower soil water evaporation (Zhang et al., 2013). For example, Fabrizzi et al. (2005) indicated that a notillage field compared to minimum tillage $(<18 \mathrm{~cm})$ has higher soil water storage $(50 \%$ higher in $0-80 \mathrm{~cm}$ soil layer) during the critical growth stage of maize, and during most of the wheat-growth season. The conclusion of our study is consistent with Fabrizzi et al. (2005). However, the difference in soil water storage between no-tillage and minimum tillage was less than $50 \%$ in our study. This can be explained because minimum tillage can cause a dry layer to form at the soil surface, which is beneficial to the water conservation of the deeper layers (Mupangwa et al., 2007; Xing et al., 2006).

A higher crop evapotranspiration in a rotation system than that in a single cropping system was in accord with Foulia et al. (2012). Alternative agricultural practices that could help balance the food demand and limited water resources in the semiarid area need to be pursued to achieve sustainable agriculture. For example, popularizing water-saving technologies (e.g., mulching, drip irrigation), integrating soil-crop system management (e.g., synchronization of the nutrient supply, soil nutrient loss, and crop demand) (Chen et al., 2011), using agronomic conservation measures (e.g., no-tillage, recycling of organic manure), and the development of drought-resistant crop varieties and the temperature seem critical for sustainable agricultural production in semiarid regions.

\subsection{Uncertainty and future work}

Uncertainties exist in this study as a result of the inaccuracy of data measurements and the analyses. First, a small sample size might increase the inaccuracy of the results. For example, there is only one year for the tillage experiments even though the sample size ( 90 samples per treatment) is adequate for statistical analysis. Second, we did not include the impacts of other climate factors (e.g., wind and solar radiation) on soil moisture, therefore we might have under- or overestimated the overall impact of climate change. It has been suggested that high wind may aggravate soil moisture evaporation and drought stress in Inner Mongolian grasslands (Jin and Gao, 2015). Third, the effects on soil moisture of other agricultural practices such as varietal improvements, technology, and policy (implicitly described by a nonclimatic factor linear trend, i.e., $\alpha_{t}$ in Eqs. (1)-(3) may also affect the analysis results. In addition, we did not consider the impacts of extreme climate events such as high temperature, which might have significantly affected soil moisture dynamics and crop growth in the critical growth period (Chen et al., 2016; Asseng et al., 2015; Tian et al., 2016). Future effort is necessary to increase the accuracy pf soil moisture data through neutron probe measurements, and consider the impacts of multi-climatic factors and extreme climate events on soil drought.

\section{Summary and conclusions}

In this study, we investigated the response of soil moisture to climate change and agricultural practices (i.e., crop type selection, continuous/crop rotation, fertilizer application, and tillage/no-tillage) in the semiarid area of northern China from 1981 to 2014 based on long-term field observational/experimental data. Our study is the first attempt to consider impacts of both climate change and multiple agricultural practices on soil moisture in the semiarid areas of northern China. Our results indicate that a warming and drying climate caused a decrease in soil moisture of $11.2 \%$ during the study period, and the drying trend in crop fields was more evident than that in grassland. Some agricultural practices (i.e., high fertilizer use, crop rotation and tillage) may result in high water consumption and low water use efficiency, and lead to excessive exploitation of water resources. Further, these may exacerbate soil drought as well as agricultural ecosystems deterioration in rainfed regions. As a result, alternative agriculture practices, such as conservation tillage, adjustment of the cropping system, and moderate fertilization, can help mitigate soil drought, securing the food supply and protecting the environment.

\section{Acknowledgments}

This study was supported by the National Natural Science Foundation of China (41371232) and the National Non-profit Research Foundation for Meteorology (GYHY201506016). We are grateful to the editors and the reviewers for their helpful comments on the manuscript.

\section{Appendix A. Supplementary data}

Supplementary data associated with this article can be found, in the online version, at http://dx.doi.org/10.1016/j.agrformet.2017.05.008.

\section{References}

Alley, R.B., Marotzke, J., Nordhaus, W., Overpeck, J., Peteet, D., Pielke, R., Pierrehumbert, R., Rhines, P., Stocker, T., Talley, L., 2003. Abrupt climate change. Science 299, 2005-2010. http://dx.doi.org/10.1126/science.1081056.

Asseng, S., Ewert, F., Martre, P., Rötter, R.P., Lobell, D.B., Cammarano, D., Kimball, B.A. Ottman, M.J., Wall, G.W., White, J.W., 2015. Rising temperatures reduce global wheat production. Nat. Clim. Change 5 (2), 143-147. http://dx.doi.org/10.1038/ nclimate 2470 .

Azooz, R.H., Lowery, B., Daniel, T.C., Arshad, M.A., 1997. Impact of tillage and residue management on soil heat flux. Agric. For. Meteorol. 84 (3), 207-222. http://dx.doi. org/10.1016/S0168-1923(96)02364-7.

Blanco-Canqui, H., Mikha, M.M., Benjamin, J.G., Stone, L.R., Schlegel, A.J., Lyon, D.J., Vigil, M.F., Stahlman, P.W., 2009. Regional study of no-till impacts on near-surface aggregate properties that influence soil erodibility. Soil Sci. Soc. Am. J. 73 (4), 1361. http://dx.doi.org/10.2136/sssaj2008.0401.

Bullock, D.G., 1992. Crop rotation. Crit. Rev. Plant Sci. 11, 309-326.

Chen, X.P., Cui, Z.L., Vitousek, P.M., et al., 2011. Integrated soil-crop system management for food security. Proc. Natl. Acad. Sci. 108 (16), 6399.

Chen, G., Tian, H., Zhang, C., et al., 2012. Drought in the Southern United States over the 20th century: variability and its impacts on terrestrial ecosystem productivity and carbon storage. Clim. Change 114 (2), 379-397. http://dx.doi.org/10.1007/s10584. 012-0410.

Chen, Y., Zhang, Z., Wang, P., Song, X., Wei, X., Tao, F.L., 2016. Identifying the impact of multi-hazards on crop yield- A case for heat stress and dry stress on winter wheat yield in northern China. Eur. J. Agron. 73, 55-63. http://dx.doi.org/10.1016/j.eja. 2015.10.009.

Cosby, B.J., Hornberger, G.M., Clapp, R.B., Ginn, T.R., 1984. A statistical exploration of the relationships of soil moisture characteristics to the physical properties of soils. Water Resour. Res. 6 (20), 682-690. http://dx.doi.org/10.1029/WR020i006p00682.

Dai, A., Trenberth, K.E., Qian, T.T., 2004. A global data set of Palmer Drought Severity 
Index for 1870-2002: relationship with soil moisture and effects of surface warming. J. Hydrometeorol. 5, 1117-1130. http://dx.doi.org/10.1175/JHM-386.1.

Deng, X.P., Shan, L., Zhang, H.P., Turner, N.C., 2006. Improving agricultural water use efficiency in arid and semiarid areas of China. Agric. Water Manag. 80, 23-40. http:// dx.doi.org/10.1016/j.agwat.2005.07.021.

Dorigo, W.J., Chung, D., Parinussa, R., Liu, Y., Wagner, W., Fernández-Prieto, D., 2012. Evaluating global trends (1988-2010) in harmonized multi-satellite surface soil moisture. Geophys. Res. Lett. 39. http://dx.doi.org/10.1029/2012GL052988.

Fabrizzi, K.P., Garcia, F.O., Costa, J.L., Picone, L.I., 2005. Soil water dynamics, physical properties and corn and wheat responses to minimum and no-tillage systems in the southern Pampas of Argentina. Soil Tillage Res. 81 (1), 57-59. http://dx.doi.org/10. 1016/j.still.2004.05.001.

Foulia, Y., Duikerb, S.W., Fritton, D.D., Hallb, M.H., Watsond, J.E., Johnsone, D.H., 2012. Double cropping effects on forage yield and the field water balance. Agric. Water Manag. 115, 104-117. http://dx.doi.org/10.1016/j.agwat.2012.08.014.

Gaiser, T., De Barros, I., Lange, F.M., Williams, J., 2004. Water use efficiency of a maize/ cowpea intercrop on a highly acidic tropical soil as affected by liming and fertilizer application. Plant Soil 263, 165-171. http://dx.doi.org/10.1023/B:PLSO. 0000047733.98854.9f.

Holsten, A., Vetter, T., Vohland, K., Krysanova, V., 2009. Impact of climate change on soil water dynamics in Brandenburg with focus on nature conservation areas. Ecol. Modell. 220, 2076-2087. http://dx.doi.org/10.1016/j.ecolmodel.2009.04.038.

Hu, Q., Pan, F.F., Pan, X.B., Zhang, D., Yang, N., Pan, Z.H., Zhao, P.Y., Tuo, D.B., 2014. Effects of a ridge-furrow micro-field rainwater-harvesting system on potato yield in a semi-arid region. Field Crops Res. 166, 92-101. http://dx.doi.org/10.1016/j.fcr. 2014.06.005.

Huang, M., Dang, T., Gallich, J., Goulet, M., 2003. Effect of increased fertilizer applications to wheat crop on soil-water depletion in the Loess Plateau, China. Agric. Water Manag. 58, 267-278. http://dx.doi.org/10.1016/S0378-3774(02)00086-0.

Jin, D.Y., Gao, Q., 2015. The influence of wind speed and mowing on soil moisture and productivity in Inner Mongolia grassland. J. Res. Arid Areas 32 (3), 461-466. http:// dx.doi.org/10.13866/j.azr.2015.03.07. (In Chinese with English abstract).

Leng, G.Y., Tang, Q.H., Rayburg, S., 2015. Climate change impacts on meteorological, agricultural and hydrological droughts in China. Glob. Planet. Change 126, 23-34. http://dx.doi.org/10.1016/j.gloplacha.2015.01.003.

Li, S., An, P.L., Pan, Z.H., Wang, F.T., Li, X.M., Liu, Y., 2015. Farmers' initiative on adaptation to climate change in the Northern Agro-pastoral Ecotone. Int. J. Disaster Risk Reduct. http://dx.doi.org/10.1016/j.ijdrr.2015.02.002i.

Liu, Y.L., Pan, Z.H., Zhuang, Q.L., Miralles, D.G., Teuling, A.J., Zhang, T.L., et al., 2015. Agriculture intensifies soil moisture decline in northern China. Sci. Rep. 5, 11261. http://dx.doi.org/10.1038/srep11261.

Lobell, D.B., Burke, M.B., 2010. On the use of statistical models to predict crop yield responses to climate change. Agric. For. Meteorol. 150, 1443-1452. http://dx.doi. org/10.1016/j.agrformet.2010.07.008.

MWRC, 2011. China Water Resources Bulletin 2011. China Water Power Press, Beijing.

$\mathrm{Ma}, \mathrm{Z} ., \mathrm{Fu}, \mathrm{C} ., 2$ 2003. Interannual characteristics of the surface hydrological variables over the arid and semi-arid areas of northern China. Glob. Planet. Change 37, 189-200. http://dx.doi.org/10.1016/S0921-8181(02)00203-5.

$\mathrm{Ma}, \mathrm{Z} ., \mathrm{Fu}, \mathrm{C} ., 2006$. Some evidence of drying trend over northern China from 1951 to 2004. Chin. Sci. Bull. 51, 2913-2925. http://dx.doi.org/10.1007/s11434-0062159-0.

Mupangwa, W., Twomlow, S., Walker, S., Hove, L., 2007. Effect of minimum tillage and mulching on maize (Zea mays L.) yield and water content of clayey and sandy soils. Phys. Chem. Earth 32 (15-18), 1127-1134. http://dx.doi.org/10.1016/j.pce.2007. 07.030 .

Özkan, U., Gökbulak, F., 2017. Effect of vegetation change from forest to herbaceous vegetation cover on soil moisture and temperature regimes and soil water chemistry. Catena 149, 158-166.

Population Census Office of China (PCOC), 2011. Main Statistics on Sixth National Population Census in China. China Statistics Press, Beijing.

Pan, S., Tian, H., Dangal, S.R.S., Yang, Q., Yang, J., Lu, C., Tao, B., Ren, W., Ouyang, Z., 2015. Responses of global terrestrial evapotranspiration to climate change and increasing atmospheric $\mathrm{CO}_{2}$ in the 21st century. Earth's Future 3, 15-35.

Piao, S., Ciais, P., Huang, Y., Shen, Z., Peng, S., Li, J., Zhou, L., Liu, H., Ma, Y., Ding, Y., 2010. The impacts of climate change on water resources and agriculture in China. Nature 467, 43-51. http://dx.doi.org/10.1038/nature09364.

Ren, W., Tian, H., Tao, B., Huang, Y., Pan, S., 2012. China's crop productivity and soil carbon storage as influenced by multifactor global change. Glob. Change Biol. 18, 2945-2957.

Reynolds, S.G., 1970. The gravimetric method of soil moisture determination Part I A study of equipment, and methodological problems. J. Hydrol. 3 (11), 258-273. http://dx doi.org/10.1016/0022-1694(70)90066-1.

Rosenzweig, C., Karoly, D., Vicarelli, M., Neofotis, P., Wu, Q., Casassa, G., Menzel, A., Root, T.L., Estrella, N., Seguin, B., 2008. Attributing physical and biological impacts to anthropogenic climate change. Nature 453, 353-357. http://dx.doi.org/10.1038/ nature06937.

Seneviratne, S.I., Corti, T., Davin, E.L., Hirschi, M., Jaeger, E.B., Lehner, I., Orlowsky, B., Teuling, A.J., 2010. Investigating soil moisture-climate interactions in a changing climate: a review. Earth Sci. Rev. 99, 125-161. http://dx.doi.org/10.1016/j. earscirev.2010.02.004.

Shaxson, F., Barber, R., 2003. Optimizing soil moisture for plant production. The significance of soil porosity. FAO Soil Bull. 79. http://hdl.handle.net/10919/65454.

Sheffield, J., Wood, E.F., 2008. Projected changes in drought occurrence under future global warming from multi-model, multi-scenario, IPCC AR4 simulations. Clim. Dyn. 31, 79-105. http://dx.doi.org/10.1007/s00382-007-0340-z.

Tao, F., Yokozawa, M., Hayashi, Y., Lin, E., 2003. Changes in agricultural water demands and soil moisture in China over the last half-century and their effects on agricultural production. Agric. For. Meteorol. 118, 251-261. http://dx.doi.org/10.1016/S01681923(03)00107-2.

Tao, F.L., Zhang, Z., Xiao, D.P., Zhang, S., Rotter, R.P., Shi, W.J., et al., 2014. Responses of wheat growth and yield to climate change in different climate zones of China. Agric. For. Meteorol. 189-190 (91-104), 1981-2009. http://dx.doi.org/10.1016/j. agrformet.2014.01.013.

Thomas, A., 2000. Climatic changes in yield index and soil water deficit trends in China. Agric. For. Meteorol. 102, 71-81. http://dx.doi.org/10.1016/S0168-1923(00) 00126-X.

Tian, H., Lu, C., Chen, G., Xu, X., Liu, M., Ren, W., Tao, B., Sun, G., Pan, S., Liu, J., 2011. Climate and land use controls over terrestrial water use efficiency in monsoon Asia. Ecohydrology 4, 322-340. http://dx.doi.org/10.1002/eco.216.

Tian, H., Lu, C.C., Melillo, J., Ren, W., Huang, Y., Xu, X.F., et al., 2012. Food benefit and climate warming potential of nitrogen fertilizer uses in China. Environ. Res. Lett. 7 (4), 1-8. http://dx.doi.org/10.1088/1748-9326/7/4/044020.

Tian, H., Ren, W., Tao, B., Sun, G., Chappelka, A., Wang, X., Pan, S., Yang, J., Liu, J., Felzer, B., Melillo, J., Reilly, J., 2016. Climate extremes and ozone pollution: a growing threat to China's food security. Ecosyst. Health Sustain. 2 (1), e01203. http://dx.doi.org/10.1002/ehs2.1203.

Tong, C., Hall, C.A., Wang, H., 2003. Land use change in rice, wheat and maize production in China (1961-1998). Agric. Ecosyst. Environ. 95, 523-536. http://dx. doi.org/10.1016/S0167-8809(02)00182-2.

Trenberth, K.E., Dai, A., Schrier, G., Jones, P.D., Barichivich, J., Briffa, K.R., Sheffield, J., 2014. Global warming and changes in drought. Nat. Clim. Change 4, 17-22. http:// dx.doi.org/10.1038/nclimate2067.

Wang, G., Chen, T.Q., Wu, W.J., Chen, H., 2010. Comparative analysis between the oven drying method and automatic observation soil humidity method. J. Meteorol. Res. Appl. 2 (31), 53-56 (In Chinese with English abstract).

Wang, A.H., Lettenmaier, D.P., Sheffield, J., 2011a. Soil moisture drought in China, 1950-2006. J. Clim. 24, 3257-3271.

Wang, D., Hejazi, M., Cai, X., Valocchi, A.J., 2011b. Climate change impact on meteorological, hydrological, and soil drought in central Illinois. Water Resour. Res. 47, W09527.

Wetherald, R.T., Manabe, S., 2002. Simulation of hydrologic changes associated with global warming. J. Geophys. Res. Atmos. (1984-2012) 107http://dx.doi.org/10 1029/2001jd001195. (ACL 7-1-ACL 7-15).

Xiao, G.J., Zheng, F.J., Qiu, Z.J., Yao, Y.B., 2013. Impact of climate change on water use efficiency by wheat, potato and corn in semiarid areas of China. Agric. Ecosyst. Environ. 181, 108-114.

Xing, G.Y., Guo, Q.Y., Wei, Y.H., Guo, L.Z., Weng, H., 2006. Effect on soil moisture, nutrient and weed control in arid farmland by shallow tillage. Sci. Agric. Sin. 39 (8), 1697-1702.

Zhang, J.J., Wang, Y., Fan, Y.L., Guo, T.W., Zhao, G., Dang, Y., Wang, L., Li, S.Z., 2013. Effects of different tillage and fertilization modes on the soil physical and chemical properties and crop yield under winter wheat/spring corn rotation on dryland of east Gansu, Northwest China. Chin. J. Appl. Ecol. 24 (4), 1001-1008. (in Chinese with English abstract). http://www.cjae.net/EN/.

Zhang, J.T., An, P.L., Pan, Z.H., et al., 2015. Adaptation to a warming-drying trend through cropping systems adjustment over three decades: a case study in the Northern Agro-Pastural Ecotone of China. J. Meteor. Res. 29. http://dx.doi.org/10. 1007/s13351-015-4083-1.

Zhao, H.L., Zhao, X.Y., Zhang, T.H., Zhou, R.L., 2002. Boundary line on agro-pasture zigzag zone in north China and its problems on eco-environment. Adv. Earth Sci. 17 $739-747$. 